\title{
Erratum
}

\section{The growth of the cell death field: an analysis from the ISI-Science citation index}

\author{
Eugene Garfield ${ }^{1}$ and Gerry Melino ${ }^{2}$ \\ 1 Chairman Emeritus, Institute of Scientific Information, Philadelphia, Pennsylvania, USA \\ 2 Corresponding author: IDI-IRCCS Biochemistry Laboratory and the University of L'Aquila, Italy
}

Our recent report (Garfield and Melino, 1997) elicited considerable interest and comment. This was the first time such an analysis has been conducted in this field. Although we anticipated that the paper was likely to be provocative, we have subsequently become aware of the limitations of the search strategy used to perform the analysis and as a consequence, certain highly cited papers were not selected. An example of this is that by Strasser et al (1991). This paper was cited about 500 times and would rank 18th place in Table 2B. Similarly, the papers by Vaux et al (1994) and Strasser et al (1994) were cited 211 and 318 times, respectively, resulting in a ranking of 2 nd and 3rd place respectively in Table $2 \mathrm{C}$. Consequently, there would also be minor adjustments in Tables 3 and 4 (most cited authors and organizations).

Any attempt at quantitative analysis of the literature, however sophisticated, must be interpreted by informed judgement. Absolute citation frequencies may be misinterpreted. It was not our intention to judge the significance of the contributions of individual scientists or institutions. We apologize if the work of a few scientists was not appropriately recognized. On the other hand, we are grateful for the interest generated by our paper. It clearly has provoked readers to reflects on the history of apoptosis. We hope to generate an updated analysis in a few years.

\section{References}

Garfield E and Melino G (1997) The growth of the cell death field: an analysis from the ISI-Science citation index. Cell Death Differ. 4: 352-361

Strasser A, Harris AW and Cory S (1991) Bcl-2 transgene inhibits T cell death and perturbs thymic self-censorship. Cell 67: 889-899

Strasser A, Harris AW, Jacks T and Cory S (1994) DNA damage can induce apoptosis in proliferating lymphoid cells via p53-independent mechanisms inhibitable by Bcl-2. Cell 79: 411-417

Vaux DL, Haecker G and Strasser A (1994) An evolutionary perspective on apoptosis. Cell 76: 777-779 